\title{
EXPERIMENTS MADE TO DETERMINE THE INFLUENCE OF TEMPERATURE ON THE DISCHARGE OF WATER FROM AN ORIFICE IN THE HEMISPHERICAL BOTTOM OF AN OPEN TOPPED CYLINDRICAL VESSEL.
}

\section{By Chief Engineer Isherwood, U. S. Navy.}

That the mobility of water is greatly influenced by its temperature, is a fact obvious on inspection to any discerning eye ; but the writer is not aware that any experiments, except those recorded in this paper, have ever been made to determine the comparative value of that influence for the different degrees of the thermometric scale. The importance of this determination in steam engineering is greater than may at first sight be apparent, for not only is the leakage of water from boilers affected by it, but also the resistance of water to motion in pipes, and to the progress of the immersed solids of vessels.

The first is of practical consequence in the testing of boilers, the second in all pumping operations, and the last in the propulsion of vessels. It will be seen from the results of these experiments that a boiler which may be tight under a given pressure when tested by the pumps with water of one temperature, may leak when tested under the same pressure with water of a higher temperature; so that a really complete test of boiler tightness requires not only that the pressure shall be equal to the steam-pressure which is to be carried in practice, but that the temperature of the water with which the test is made shall be the same as the temperature normal to this steampressure. Again, in pumping operations, it will be seen that the duty of a pumping-engine cannot be accurately calculated for the weight of water raised and the height to which it is elevated alone, because it must have a correction for the influence of the temperature of the water, as the higher that is, the less, in some ratio, will be the resistance the water opposes to the engine. The higher the temperature, the greater is the freedom with which the molecules glide over and around each other, causing the water to deflect more easily along the sinuosities of the pipes, and to receive less resistance from their surfaces. In the propulsion of vessels, the water of higher temperature opposes, for the same reasons, less resistance to their passage than water of lower temperature, even allowing for their greater draught in the warmer water due to its less density. 
In the various determinations which have heretofore been made of the ratio of the actual to the theoretical discharge of water through orifices, the temperature of the water should have been noted, as the actual discharges, ceteris paribus, are affected by it, while the theoretical discharge remains constant at all temperatures. The experimental ratios are true for only the experimental temperatures, and need reduction to a standard temperature.

\section{Description of the Apparatus.}

Fia. 1 .

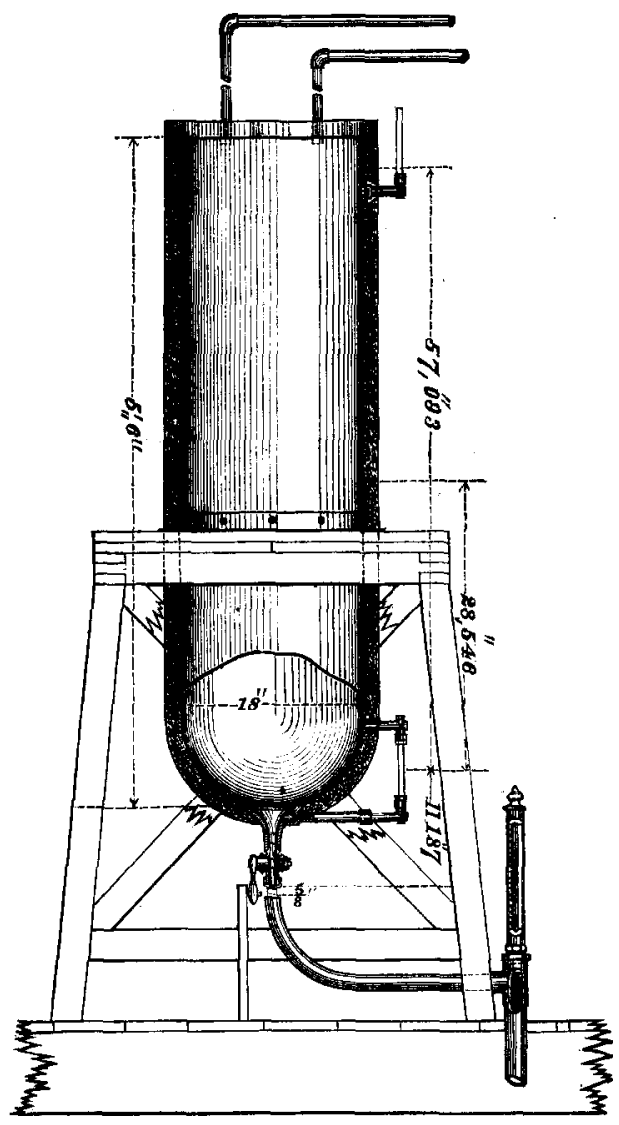

The apparatus, Fig. 1, consisted of a vertical cylinder, 18 inches in external diameter, with an open top and a hemispherical bottom, the whole being $5 \mathrm{ft} .6$ in. in height, and made of copper as thin as consistent with rigidity of form. The lower part of the bottom had an aperture of 4 inches diameter, to which was bolted a vertical brass bell-mouth of 4 inches internal diameter at top, and $1 \frac{1}{16}$ in. internal diameter at bottom, the sides being formed of converging curves. The bell-mouth was $4 \frac{1}{8}$ inches in internal height, and its axis was in the same vertical as that of the cylinder; near its top was a horizontal cylindrical nozzle, into which was screwed a small water-pipe communicating with the lower glass water-gauge. Into the bottom of the bell-mouth an ordinary stop-cock was screwed, having a water-way of 0.77 inch 
diameter, to which was adjusted a washer or disc of brass (see Fig. 2 ), one-fourth of an inch thick, perforated with a hole of five-eighths of an inch least diameter, the sides of this hole were rounded on a semi-circle, and its axis was in the same straight line with the vertical axis of the stop-cock and bell-mouth.

At 1 inch below the washer was placed a pipe of $1 \frac{1}{4}$ inches inner diameter, to receive the water discharged, the column of which was therefore in open view. This pipe was curved laterally, and connected to a vertical drain-pipe of $1 \frac{1}{2}$ inches inner diameter, situated 6 inches from the axis of the cylinder. In the vertical pipe was placed a large thermometer with a long bulb, protected by a perforated casing of brass. The bulb was opposite and below the junction of the two pipes, so that the water discharged flowed freely over it. The apparatus was supported upon a stout wooden framing, by means of a brass flange, riveted to the cylinder. Attached to the side of the cylinder were two glass watergauges, having their vertical axes in the same straight line, one near the top, and the other near the bottom.

The open top of the cylinder had a wooden cover, part of which was screwed fast to the cylinder, and

Fig. 2.

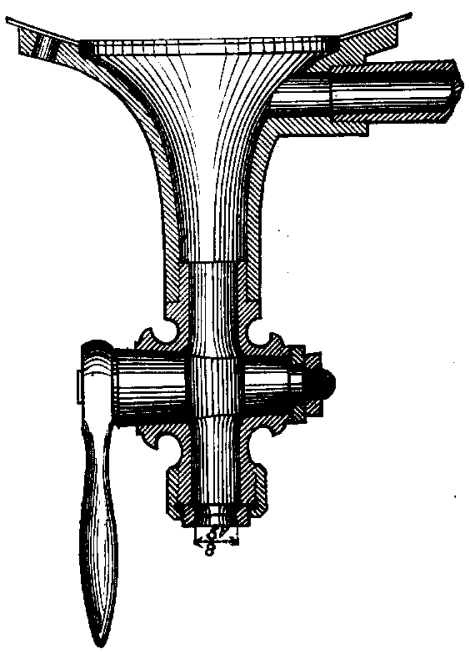
had passing through it two pipes, one leading to the water space of a steam boiler in use, and the other to the water of the Croton aqueduct. Both pipes were fitted with suitable stop-valves, and by their means the cylinder could be filled with water of any temperature between $32^{\circ}$ and $212^{\circ} \mathrm{Fahr}$. The remaining part of the cover was removable, and was perforated with a number of small holes, to allow the escape of the steam when the valve in the hot-water pipe-or pipe connecting with the boiler-was open.

The entire cylinder and its hemispherical bottom were closely covered with felt $1 \frac{1}{2}$ inches in thickness.

The apparatus was erected in the engine-room of the boiler-shop of the "Novelty Iron Works" in the city of New York, and all its 
appendages being complete and found perfectly tight, the cylinder was nearly filled with water, and a permanent mark made at its level on the upper glass water-gauge. Eight and one-half cubic feet of water were then measured out of the vessel, drawing it off into a box of exactly one cubic foot capacity, made especially for the purpose; this brought the water-level to a convenient point for observation in the lower glass water-gauge, which point was permanently marked on the lower gauge in a similar manner to the upper one.

\section{Manner of making the Experiments.}

In commencing an experiment, the cylinder was filled to a few inches above the mark on the upper glass water-gauge, with water, either from the boiler or from the Croton aqueduct, or frem both, according to the temperature desired. In the latter case, the water was let in simultaneously from both pipes, so as to mix as the cylinder filled, and the mixing was made more thorough by stirring the water in the eylinder with a board having a surface on one side of about half a square foot. This board was fitted with a long handle at right angles to its surface. As soon as the water became quiescent the discharge-cock was opened, and the exact times were noted when the water-level was at the mark on the upper glass water-gauge, and at the mark on the lower glass water-gauge. During the discharge of the water between the marks on the gauges, the thermometer was noted every minute, and the mean of the observations taken for the temperature of the water. As, the cylinder was filled about 2 inches above the upper mark, the water had sufficient time to acquire its velocity in descending to that mark, independently of the time consumed in opening the discharge-cock. It will be observed that the area of the water-way through the plug of this cock was nearly one and a half times the area of the discharge-orifice through the washer; therefore, no small difference in the opening of the cock could influence the freedom of the discharge; but, to prevent any question, a stop was properly fixed, so that the handle of the cock always opened against it. The discharge orifice was not changed during the experiments; and the column of water issuing from it being in full view, any accidental obstruction, had any occurred, would have been immediately detected. The water entered the lateral pipe in the form of a smooth cylinder, except at the highest temperatures, and losing there tho 
greater part of its velocity, flowed around the bulb of the thermometer, and passed into the drain-pipe. During a portion of the experiments the time was noted by a stop-watch, but it was found that by holding a common watch in such manner as to bring the second hand close to the marks on the glass water-gauges, the eye could note the time fully as quickly and as accurately as the thumb could press the spring of the stop-wateh. When filling the cylinder with a mixture of hot and cold water, both were allowed to run in at the same time, and the equality of the temperature of the mass was assured. By carefully observing this simple process, the temperature, when low, of the discharging water, would not vary over a degree, and when high, not over four or five degrees between extremes. The temperature of the water from the Croton aqueduct was, for most of the time, about 37 degrees Fahrenheit, and for experiments with lower temperatures it was reduced by ice, in which cases the water was thoroughly stirred and the unmelted lumps of ice skimmed off before opening the discharge-cock. The water used in the boiler was also from the Croton aqueduct.

The experiments were two hundred and forty-six in number. They occupied many days, and were about equally distributed between the temperatures of 32 degrees and 212 degrees Fahrenheit. From their corrected results the following table was formed by laying off by scale, on a straight line, the observed temperatures as abscissa, and erecting at right angles to this line, as ordinates, the corresponding times by scale of discharge, drawing as nearly as possibje, through the free ends of the latter, a fair curve, leaving as many points on one side of it as on the other. From the graphic curve thus obtained, the times in seconds of the discharges of the eight and a half cubic feet of water of every degree of temperature on Fahrenheit's scale, from $32^{\circ}$ to $212^{\circ}$, were accurately measured off by scale. These times, for every fourth degree, will be found in the second column of the table, and are, of course, for equal volumes. In the fourth column of the table will be found the times in seconds of the discharges of equal weights of water of the temperatures in the first column, taking the weight to be that due to the eight and a half cubic feet at the temperature of $39^{\circ} \mathrm{Fahrenheit;} \mathrm{these} \mathrm{quantities}$ are derived from those in the second column by modifying the latter according to Kopp's determination of the relative volumes of an equal weight of water at different temperatures. 
T A B L E

Exhibiting the Results of Experimente made for the Purpose of Determining the Effect of Temperature on the Discharge of Water from an Orifice in the Hemispherical Bottom of an Open Topped Cylindrloal Vesset.

\begin{tabular}{|c|c|c|c|c|c|c|}
\hline \multirow{3}{*}{ 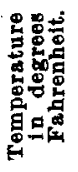 } & \multicolumn{4}{|c|}{ Time of Dibcharea in Seconda. } & \multirow{2}{*}{\multicolumn{2}{|c|}{$\begin{array}{c}\text { ReLative VhLoOitike or } \\
\text { DisohakgR. }\end{array}$}} \\
\hline & \multicolumn{2}{|c|}{ For equal volumes. } & \multicolumn{2}{|c|}{ For equal weights. } & & \\
\hline & Absolute. & Relative. & Absolute. & Relative. & $\begin{array}{l}\text { For equal } \\
\text { volumes. }\end{array}$ & $\begin{array}{l}\text { For equal } \\
\text { weights. }\end{array}$ \\
\hline $\begin{array}{l}32 \\
36 \\
40 \\
44\end{array}$ & $\begin{array}{l}848 \cdot 25 \\
847 \cdot 20 \\
845 \cdot 95 \\
844 \cdot 80\end{array}$ & $\begin{array}{l}1.0000 \\
0.9988 \\
0.9973 \\
0.9959\end{array}$ & $\begin{array}{l}848 \cdot 3425 \\
847 \cdot 2169 \\
845 \cdot 9517 \\
844.8448\end{array}$ & $\begin{array}{l}1.0000 \\
0.9987 \\
0.9972 \\
0.9959\end{array}$ & $\begin{array}{l}1 \cdot 0000 \\
1 \cdot 0012 \\
1 \cdot 0027 \\
1.0041\end{array}$ & $\begin{array}{l}1 \cdot 0000 \\
1 \cdot 0013 \\
1 \cdot 0028 \\
1 \cdot 0041\end{array}$ \\
\hline $\begin{array}{l}48 \\
\mathbf{5 2} \\
\mathbf{5 6} \\
60\end{array}$ & $\begin{array}{l}843 \cdot 55 \\
842 \cdot 15 \\
840 \cdot 85 \\
839 \cdot 40\end{array}$ & $\begin{array}{l}0.9944 \\
0.9928 \\
0.9913 \\
0.9896\end{array}$ & $\begin{array}{l}843 \cdot 6942 \\
842 \cdot 4473 \\
841 \cdot 3520 \\
840 \cdot 1563\end{array}$ & $\begin{array}{l}0.9945 \\
0.9930 \\
0.9917 \\
0.9903\end{array}$ & $\begin{array}{l}1 \cdot 0056 \\
1 \cdot 0072 \\
1 \cdot 0087 \\
1 \cdot 0105\end{array}$ & $\begin{array}{l}1 \cdot 0055 \\
1 \cdot 0070 \\
1 \cdot 0084 \\
1 \cdot 0097\end{array}$ \\
\hline $\begin{array}{l}64 \\
68 \\
72 \\
76\end{array}$ & $\begin{array}{l}887 \cdot 85 \\
836 \cdot 30 \\
834 \cdot 70 \\
833 \cdot 10\end{array}$ & $\begin{array}{l}0.9877 \\
0.9859 \\
0.9840 \\
0.9821\end{array}$ & $\begin{array}{l}838 \cdot 9074 \\
837 \cdot 7050 \\
836 \cdot 4954 \\
835 \cdot 3285\end{array}$ & $\begin{array}{l}0.9889 \\
0.9875 \\
0.9860 \\
0.9846\end{array}$ & $\begin{array}{l}1 \cdot 0124 \\
1 \cdot 0143 \\
1 \cdot 0163 \\
1 \cdot 0182\end{array}$ & $\begin{array}{l}1 \cdot 0112 \\
1 \cdot 0127 \\
1 \cdot 0143 \\
1 \cdot 0158\end{array}$ \\
\hline $\begin{array}{l}80 \\
84 \\
88 \\
92\end{array}$ & $\begin{array}{l}831 \cdot 50 \\
829 \cdot 70 \\
827 \cdot 95 \\
826 \cdot 20\end{array}$ & $\begin{array}{l}0.9802 \\
0.9781 \\
0.9761 \\
0.9740\end{array}$ & $\begin{array}{l}834 \cdot 2015 \\
832 \cdot 9126 \\
831 \cdot 7105 \\
880 \cdot 5441\end{array}$ & $\begin{array}{l}0.9833 \\
0.9818 \\
0.9804 \\
0.9790\end{array}$ & $\begin{array}{l}1 \cdot 0202 \\
1 \cdot 0224 \\
1 \cdot 0245 \\
1 \cdot 0267\end{array}$ & $\begin{array}{l}1 \cdot 0170 \\
1 \cdot 0186 \\
1 \cdot 0200 \\
1 \cdot 0213\end{array}$ \\
\hline $\begin{array}{r}96 \\
100 \\
104 \\
108\end{array}$ & $\begin{array}{l}824 \cdot 35 \\
822 \cdot 50 \\
820 \cdot 65 \\
818 \cdot 75\end{array}$ & $\begin{array}{l}0.9718 \\
0.9696 \\
0.9675 \\
0.9652\end{array}$ & $\begin{array}{l}829 \cdot 3118 \\
828 \cdot 1111 \\
826 \cdot 9427 \\
825 \cdot 7586\end{array}$ & $\begin{array}{l}0.9775 \\
0.9761 \\
0.9748 \\
0.9734\end{array}$ & $\begin{array}{l}1 \cdot 0290 \\
1 \cdot 0813 \\
1 \cdot 0336 \\
1 \cdot 0360\end{array}$ & $\begin{array}{l}1 \cdot 0230 \\
1 \cdot 0245 \\
1 \cdot 0258 \\
1 \cdot 0273\end{array}$ \\
\hline $\begin{array}{l}112 \\
116 \\
120 \\
124\end{array}$ & $\begin{array}{l}816 \cdot 85 \\
814 \cdot 85 \\
812 \cdot 90 \\
810 \cdot 85\end{array}$ & $\begin{array}{l}0.9630 \\
0.9606 \\
0.9583 \\
0.9559\end{array}$ & $\begin{array}{l}824 \cdot 5929 \\
823 \cdot 3587 \\
822 \cdot 2012 \\
820 \cdot 9678\end{array}$ & $\begin{array}{l}0.9720 \\
0.9705 \\
0.9691 \\
0.9677\end{array}$ & $\begin{array}{l}1 \cdot 0384 \\
1 \cdot 0410 \\
1 \cdot 0436 \\
1 \cdot 0461\end{array}$ & $\begin{array}{l}1 \cdot 0288 \\
1 \cdot 0304 \\
1 \cdot 0319 \\
1 \cdot 0330\end{array}$ \\
\hline $\begin{array}{l}128 \\
132 \\
136 \\
140\end{array}$ & $\begin{array}{l}808 \cdot 75 \\
806 \cdot 60 \\
804 \cdot 40 \\
802 \cdot 20\end{array}$ & $\begin{array}{l}0.9534 \\
0.9509 \\
0.9483 \\
0.9457\end{array}$ & $\begin{array}{l}819 \cdot 7086 \\
818 \cdot 4207 \\
817 \cdot 1081 \\
815 \cdot 8069\end{array}$ & $\begin{array}{l}0.9662 \\
0.9646 \\
0.9681 \\
0.9616\end{array}$ & $\begin{array}{l}1 \cdot 0489 \\
1 \cdot 0516 \\
1 \cdot 0545 \\
1 \cdot 0577\end{array}$ & $\begin{array}{l}1 \cdot 0350 \\
1 \cdot 0367 \\
1 \cdot 0383 \\
1 \cdot 0399\end{array}$ \\
\hline $\begin{array}{l}144 \\
148 \\
152 \\
156\end{array}$ & $\begin{array}{l}799 \cdot 90 \\
797 \cdot 70 \\
795 \cdot 30 \\
792 \cdot 90\end{array}$ & $\begin{array}{l}0.9430 \\
0.9404 \\
0.9376 \\
0.9347\end{array}$ & $\begin{array}{l}814 \cdot 4286 \\
813 \cdot 1706 \\
811 \cdot 7269 \\
810 \cdot 3002\end{array}$ & $\begin{array}{l}0.9600 \\
0.9585 \\
0.9568 \\
0.9551\end{array}$ & $\begin{array}{l}1 \cdot 0604 \\
1 \cdot 0633 \\
1 \cdot 0665 \\
1 \cdot 0698\end{array}$ & $\begin{array}{l}1 \cdot 0416 \\
1 \cdot 0434 \\
1 \cdot 0451 \\
1 \cdot 0469\end{array}$ \\
\hline $\begin{array}{l}160 \\
164 \\
168 \\
172\end{array}$ & $\begin{array}{l}790 \cdot 40 \\
787 \cdot 80 \\
785 \cdot 10 \\
782 \cdot 30\end{array}$ & $\begin{array}{l}0.9318 \\
0.9287 \\
0.9255 \\
0.9222\end{array}$ & $\begin{array}{l}808 \cdot 7863 \\
807 \cdot 1838 \\
805 \cdot 4953 \\
803 \cdot 7147\end{array}$ & $\begin{array}{l}0.9534 \\
0.9515 \\
0.9495 \\
0.9474\end{array}$ & $\begin{array}{l}1 \cdot 0732 \\
1 \cdot 0767 \\
1 \cdot 0804 \\
1 \cdot 0843\end{array}$ & $\begin{array}{l}1 \cdot 0489 \\
1 \cdot 0509 \\
1 \cdot 0532 \\
1 \cdot 0555\end{array}$ \\
\hline $\begin{array}{l}176 \\
180 \\
184 \\
188\end{array}$ & $\begin{array}{l}779 \cdot 60 \\
776 \cdot 70 \\
773 \cdot 70 \\
770 \cdot 80\end{array}$ & $\begin{array}{l}0.9191 \\
0.9156 \\
0.9121 \\
0.9087\end{array}$ & $\begin{array}{c}802 \cdot 0494 \\
800 \cdot 1990 \\
798 \cdot 2356 \\
796 \cdot 3944\end{array}$ & $\begin{array}{l}0.9454 \\
0.9432 \\
0.9409 \\
0.9388\end{array}$ & $\begin{array}{l}1 \cdot 0880 \\
1 \cdot 0922 \\
1 \cdot 0963 \\
1 \cdot 1005\end{array}$ & $\begin{array}{l}1 \cdot 0577 \\
1 \cdot 0604 \\
1 \cdot 0628 \\
1 \cdot 0652\end{array}$ \\
\hline $\begin{array}{l}192 \\
196 \\
200 \\
204\end{array}$ & $\begin{array}{l}767 \cdot 75 \\
764 \cdot 50 \\
761 \cdot 30 \\
757 \cdot 90\end{array}$ & $\begin{array}{l}0.9051 \\
0.9012 \\
0.8975 \\
0.8935\end{array}$ & $\begin{array}{l}794 \cdot 4070 \\
792 \cdot 2200 \\
790 \cdot 0916 \\
787 \cdot 7605\end{array}$ & $\begin{array}{l}0.9365 \\
0.9338 \\
0.9313 \\
0.9286\end{array}$ & $\begin{array}{l}1 \cdot 1048 \\
1 \cdot 1096 \\
1 \cdot 1141 \\
1 \cdot 1192\end{array}$ & $\begin{array}{l}1 \cdot 0678 \\
1.0708 \\
1.0736 \\
1.0769\end{array}$ \\
\hline $\begin{array}{l}208 \\
212\end{array}$ & $\begin{array}{l}754 \cdot 50 \\
751 \cdot 10\end{array}$ & $\begin{array}{l}0.8895 \\
0.8855\end{array}$ & $\begin{array}{l}785 \cdot 4345 \\
783 \cdot 1134\end{array}$ & $\begin{array}{l}0.9258 \\
0.9231\end{array}$ & $\begin{array}{l}1 \cdot 1241 \\
1 \cdot 1293\end{array}$ & $\begin{array}{l}1 \cdot 0801 \\
1 \cdot 0833\end{array}$ \\
\hline
\end{tabular}


The experimental results were corrected for the varying area of the discharge aperture according to the temperature of the water passing through it; the mean linear dilatation of the brass for each degree Fahrenheit, between the temperatures of $32^{\circ}$ and $212^{\circ} \mathrm{Fahr}$ enheit, being taken at 0.00001052 of the length at $32^{\circ}$.

These experiments were made in 1863, and the writer's duties at that time, as Chief of the Bureau of Steam Engineering in the Navy Department, preventing him from giving them his personal attention, they were very carefully and skilfully conducted for him, after the apparatus was constructed, and the manner of experimenting arranged, by Mr. Charles E. Emery, then an engineer in the United States Navy, from whose tabular records or logs of the experiments the writer, after making the corrections above stated, protracted the graphic curve representing their results, and from it constructed the foregoing table. The headings of the columns in this table are so descriptive of their contents as to need no further elucidation.

A remarkable result of these experiments is that the relative velocities of discharge for equal weights of water at different temperatures, are in the ratio of the squares of the relative volumes of equal weights of water at the same temperatures.

\section{FALL OF A HYDRAULIC ELEVATOR AT THE GRAND HOTEL IN PARIS, FRANCE.}

$$
\text { By W. Barnet Le Van. }
$$

On Sunday morning, February 24th, 1878, the car of the hydraulic elevator of the Grand Hotel being at the second floor, two passengers and the conductor entered it, for the purpose of descending to the first floor.

The conductor started the car to lower, but, instead of descending, the car began to ascend with an alarming rapidity. The casting which connected the piston to the bottom of the car had parted. The car, in ascending to the second floor, was lifted by the pressure of the water under the piston, as usual, but on the opening of the 